\title{
Particulate nucleic acid dynamics in a highly oligotrophic system: the Cretan Sea (Eastern Mediterranean)
}

\author{
A. Dell'Anno ${ }^{1}$, D. Marrale ${ }^{2}$, A. Pusceddu ${ }^{1}$, M. Fabiano ${ }^{2}$, R. Danovaro ${ }^{1,3, *}$ \\ ${ }^{1}$ Institute of Marine Science, University of Ancona, Via Brecce Bianche, 60131 Ancona, Italy \\ ${ }^{2}$ Department for the Study of the Territory and Its Resources, University of Genova, Corso Europa 26, 16132 Genova, Italy \\ ${ }^{3}$ Department of Zoology, University of Bari, Via Orabona 4, 70125 Bari, Italy
}

\begin{abstract}
Spatial and temporal variations of nucleic acid (DNA and RNA) concentrations and bacterioplankton density were investigated in a highly oligotrophic region of the Eastern Mediterranean in order to evaluate the relative contribution of the pico-, nano- and microparticulate fractions and to estimate bacterioplankton contribution to the nucleic acid pools. The oligotrophic conditions of the Cretan Sea were reflected by the extremely low particulate nucleic acid content. In particular, RNA concentrations (range: 0.1 to $3.8 \mu \mathrm{g} \mathrm{l}^{-1}$ ) were the lowest reported so far in the marine environment. Particulate DNA concentrations (range: 0.8 to $5.9 \mu \mathrm{g} \mathrm{l}^{-1}$ ) also displayed a reduced temporal variability. Picoparticulate RNA and bacterial secondary production displayed similar spatial patterns, suggesting that RNA concentrations increased as a result of enhanced metabolic activity. High DNA concentrations were generally associated with the high salinity (>38.95) Transition Mediterranean Waters (TMW) in summer (August 1994 and September 1995), whereas a sharp decrease in DNA concentrations was observed in non-stratified conditions (e.g. February 1995). Most of the DNA concentration was associated with picoparticles (more than $60 \%$ of total DNA pool), with a ratio of 1:3:6 for micro-, nano- and picoparticulate fractions, respectively. By contrast, particulate proteins and RNA displayed an average annual ratio of about 1:1:2 for micro-, nano-, and picoparticulate fractions, respectively, Bacterial densities in the Cretan Sea ranged from 1.1 to $8.8 \times 10^{8} \mathrm{Cells}^{-1}$. The bacterial DNA contribution to the total DNA pool in the Cretan Sea was on average $40 \%$, but in February 1995 the living DNA fraction accounted for $85 \%$ of the total DNA pool. As phytoplankton DNA annually accounted on average for only $17 \%$ of the total DNA, we conclude that bacteria play a role of primary importance as a living DNA component in the Cretan Sea.
\end{abstract}

KEY WORDS: Particulate nucleic acids · Bacterioplankton · Eastern Mediterranean

\section{INTRODUCTION}

A large proportion of the particulate DNA in the water column and in the sediments (up to $90 \%$ of the total sedimentary DNA pools; Dell'Anno et al. 1998) is associated with dead cells and/or absorbed to particles (i.e. detrital DNA; Holm-Hansen et al. 1968, Winn \& Karl 1986). The nature and diagenesis of such detrital DNA is, to a large extent, uncertain (Bailiff \& Karl 1991). DNA composition is characterised by a large content of organic N and P relative to organic C (C:N:P

-Addressee for correspondence.

E-mail: danovaro@popcsi.unian.it
$=10: 4: 1$; Maruyama et al. 1993). Therefore, despite the relatively low concentrations of DNA in most marine environments, detrital nucleic acids might represent a potentially important trophic source (Paul et al. 1987), and in extremely oligotrophic environments, where $\mathrm{N}$ and $\mathrm{P}$ limit heterotrophic metabolism (Zweifel et al. 1993, Danovaro 1998), might become key source molecules. Previous studies have shown strongly decreasing gradients of particulate DNA concentrations from the coast to the open sea (i.e. with changing trophic conditions; Paul \& Carlson 1984, Paul et al. 1985, Boheme et al. 1993). In surface oceanic waters, most of the particulate DNA and bacteria are associated with the smallest size fractions of the suspended particles 
Filter blanks were obtained from the 3 different pore size filters used. The detection limit was estimated through analysis of the blanks added with internal standards (final concentrations $0.5,1.0,1.5,2.5,5.0 \mu \mathrm{g}$ $\mathrm{ml}^{-1}$ ). The sensitivity of the method was $\pm 2.0 \mu \mathrm{g}$.

Bacterial analyses. Bacterial abundance was determined by epifluorescence microscopy according to Hobbie et al. (1977). Subsamples were stained with Acridine Orange and filtered onto black Nuclepore $0.2 \mu \mathrm{m}$ filters. Analyses were carried out for 3 to 5 replicates per sample. Two filters per replicate were processed. At least 400 cells were counted from each filter. Additional counts for bacteria attached to suspended particles larger than $2.0 \mu \mathrm{m}$ were carried out in August 1994. Bacterial densities reported in this study must be considered as the sum of autotrophic and heterotrophic components. Bacterial DNA content was estimated assuming a conversion factor of $2.5 \mathrm{fg}$ of DNA (Simon \& Azam 1989) for cells displaying an average size similar to that encountered in this study (modal class $0.065 \mu^{3}$, data not shown).

\section{RESULTS}

\section{Seasonal and spatial changes in total particulate DNA and RNA concentrations}

To point out differences in nucleic acid concentrations and their distribution among the 3 different size classes, data were grouped according to hydrology and water column structure into: (1) surface concentrations (samples collected down to $100 \mathrm{~m}$ depth, i.e. particles associated with the surface waters, MAW and CIW); (2) deep water concentrations (>100 $\mathrm{m}$ depth, i.e. particles associated with TMW and the CDW). The depth of 100 $m$ was also selected because it corresponded to the maximum depth of the photic layer (Psarra et al. 1996).

Spatial and temporal variations of total particulate DNA and RNA concentrations are illustrated in Fig. 3. Particulate DNA concentrations showed limited temporal changes ranging, on average over the entire data set, between $2.1 \pm 1.0$ (February 1995) and $3.1 \pm 1.4 \mu \mathrm{g} \mathrm{l}^{-1}$ (August 1994). The highest value was measured in
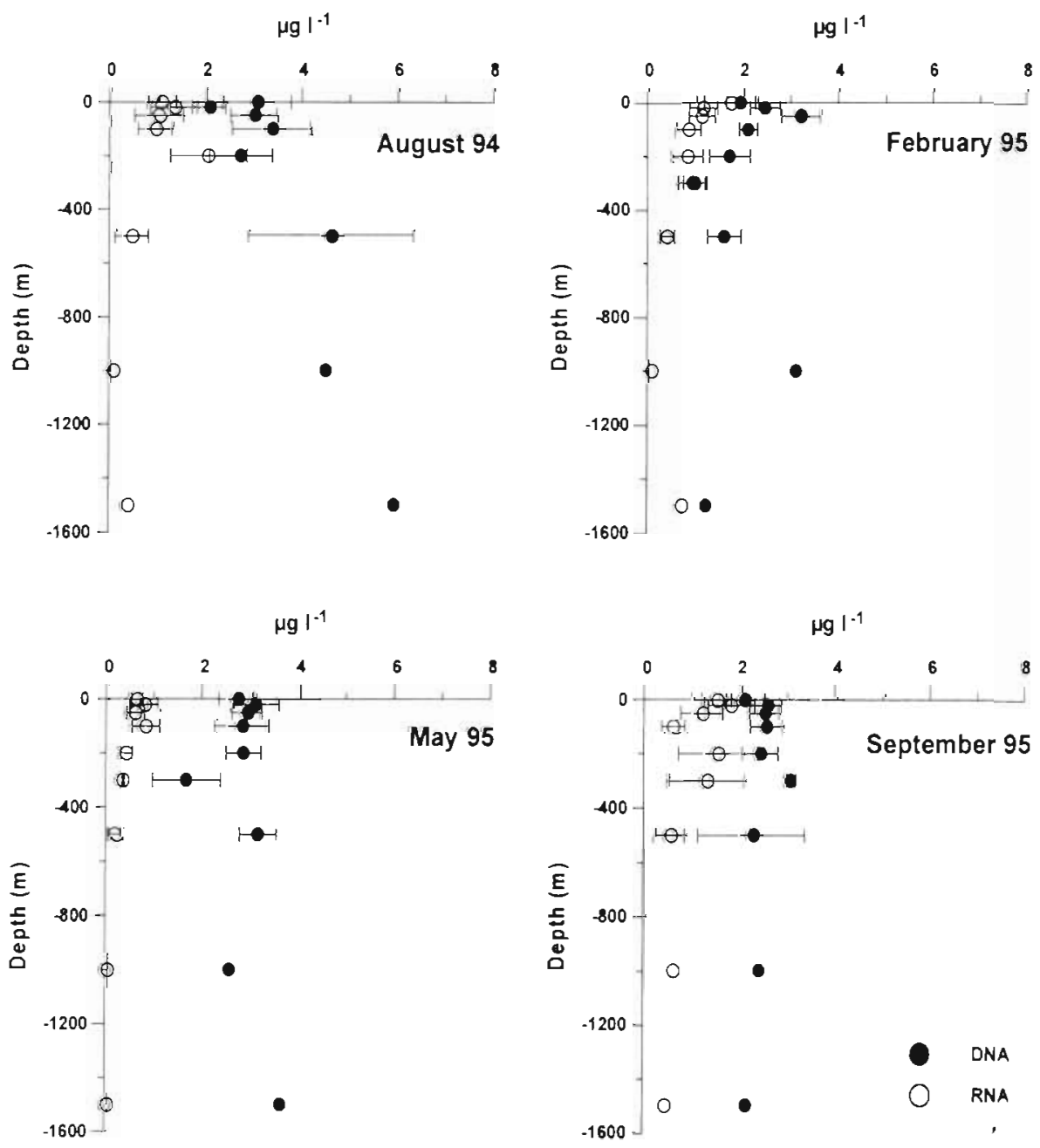

Fig. 3. Vertical profiles of DNA and RNA concentrations in the 4 sampling periods. Reported are average values of all sampled stations at each depth and relative standard errors 
August 1994 at $\operatorname{Stn} D 7\left(7.9 \mu \mathrm{g} \mathrm{l}^{-1}\right.$ at $500 \mathrm{~m}$ depth), while the lowest concentration was reported in February 1995 at Stn D6 (0.38 $\mathrm{gg} \mathrm{l}^{-1}$ at $200 \mathrm{~m}$ depth). Surface DNA concentrations increased by about 4 -fold from the coast to the open sea. DNA vertical distributions revealed significantly higher $(t$-test, $p<0.01)$ concentrations in surface waters $\left(5.0 \pm 0.7 \mathrm{\mu g} \mathrm{l}^{-1}\right)$ than in deeper water layers $(2.5$ $\pm 0.7 \mu \mathrm{g} \mathrm{l}^{-1}$ ). Generally 2 main peaks were observed, one in surface waters and another in deeper water layers. These latter deep DNA peaks were particularly evident in August 1994 and May and September 1995, between 300 and $500 \mathrm{~m}$ depth.

RNA concentrations varied in a narrow range, on average over the entire data set, from $0.5 \pm 0.5$ (May 1995) to $1.2 \pm 1.1 \mu \mathrm{gl}^{-1}$ (September 1995). Integrated RNA concentrations in the surface waters did not show a clear coast to open sea pattern. RNA concentrations displayed a clear decrease with increasing water depth, being significantly higher $(t$-test, $p<0.02)$ in surface waters $(2.7 \pm$ $\left.0.8 \mathrm{\mu g} \mathrm{l}^{-1}\right)$ than in deeper water layers $\left(0.71 \pm 0.3 \mu \mathrm{g} \mathrm{l}^{-1}\right)$.

\section{Nucleic acids associated with different particle sizes}

The distribution of total DNA concentrations (expressed as percentages) among the 3 particle size classes is reported in Fig. 4. DNA associated with the picoparticulate fraction (hereafter referred to as picoparticulate DNA) displayed the highest concentrations and was dominant in all sampling periods, accounting on average for $62 \%$ of total DNA annually. DNA associated with the nanoparticulate and microparticulate fractions accounted on average for 27 and $11 \%$ annually, respectively. In the top $100 \mathrm{~m}$ of the water column (Fig. 4a), no significant temporal changes were observed in the relative importance of the 3 size fractions. By contrast, below $100 \mathrm{~m}$ depth (Fig. $4 \mathrm{~b})$, significant changes $(F=3.403$, $\mathrm{p}=0.02$ ) were observed between sampling periods (with picoparticulate DNA ranging from 43 to $70 \%$ ).

The picoparticulate RNA annually accounted on average for $48 \%$ of the total RNA concentrations, followed by nano- (on average $29 \%$ ) and microparticulate fractions (on average $23 \%$; Fig. 5). The contribution of the microparticulate RNA to the total RNA pool was rather constant in all sampling periods (on average $23 \%$, range 21 to $24 \%$ ). Therefore, temporal changes in the contribution of the nanoparticulate RNA fraction (in May up to $43 \%$ ) were balanced by changes in the picoparticulate RNA (minimum value in May, $34 \%$ ).

\section{Chloroplastic pigment concentrations}

Chl a concentrations in September 1995 (Fig. 6) were very low (on average $0.06 \mathrm{\mu g} \mathrm{l}^{-1}$ in the top $100 \mathrm{~m}$

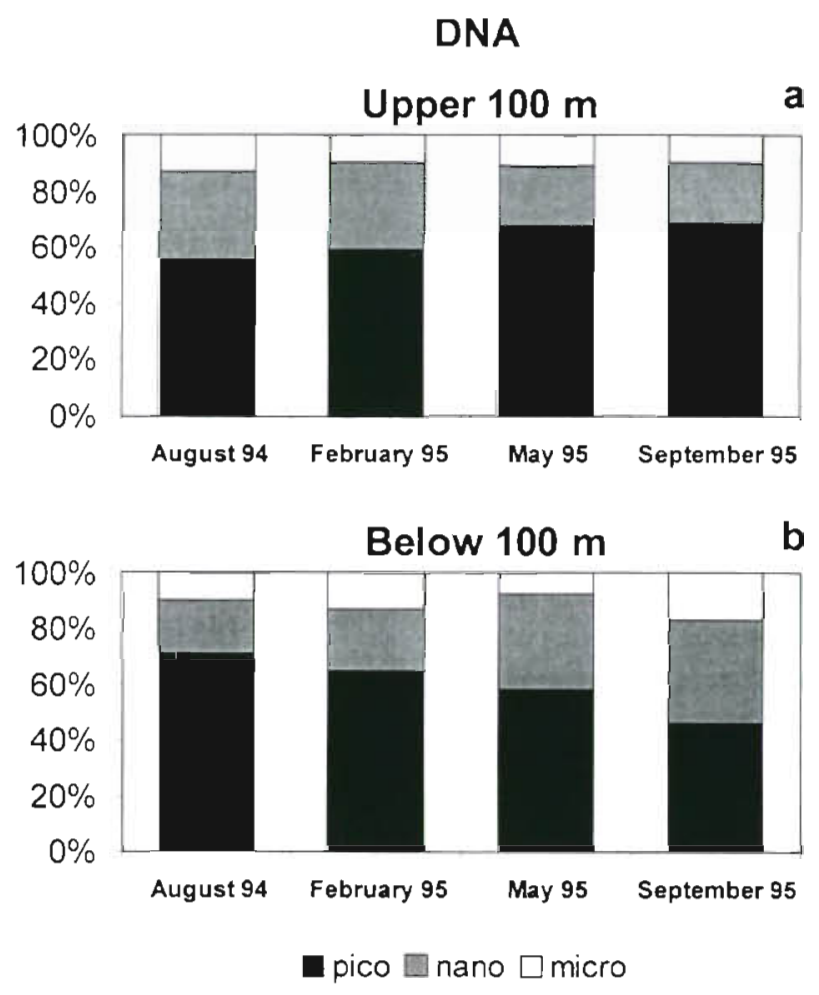

Fig. 4. Relative significance of the pico-, nano- and microparticulate fractions to the total particulate DNA pool (a) in the top $100 \mathrm{~m}$ of the water column and (b) below $100 \mathrm{~m}$ depth

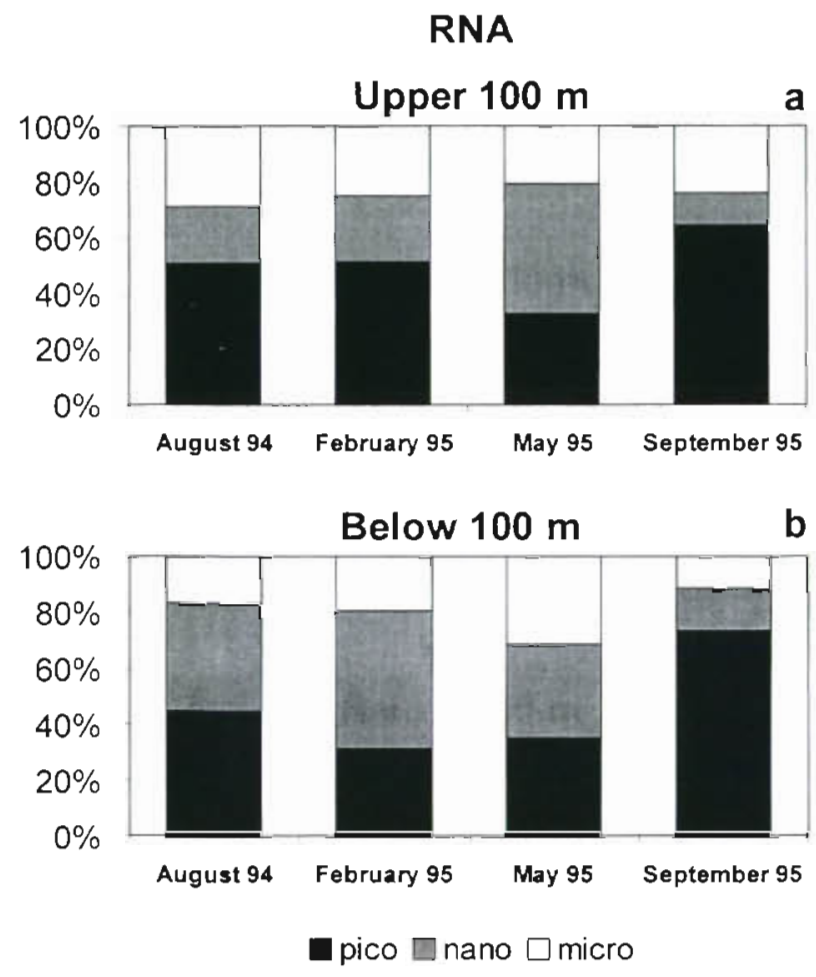

Fig. 5. Relative significance of the pico-, nano- and microparticulate fractions to the total particulate RNA pool (a) in the top $100 \mathrm{~m}$ of the water column and (b) below $100 \mathrm{~m}$ depth 


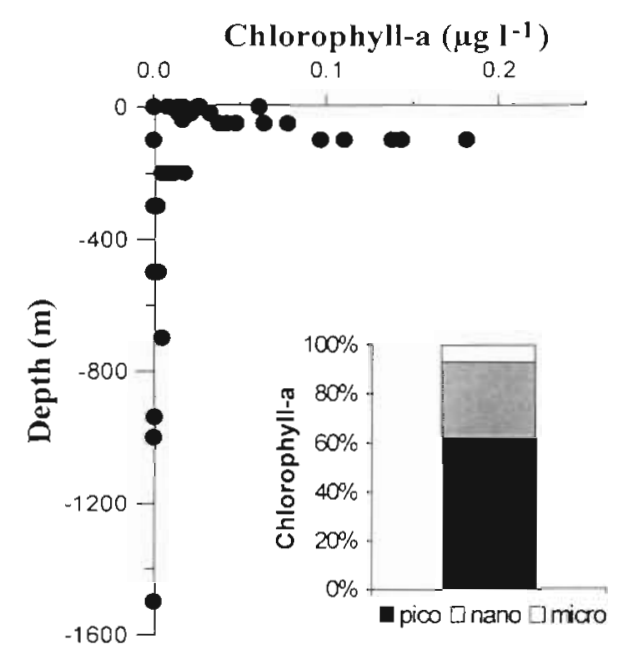

Fig. 6. Vertical profiles of chlorophyll a concentrations in September 1995. Inset: contribution of the different size classes to the total chlorophyll a content

depth). At Stns D2, D3, D4, D5 and D7 a deep chlorophyll maximum $\left(0.07\right.$ to $\left.0.16 \mu \mathrm{g}^{-1}\right)$ was observed at $100 \mathrm{~m}$ depth. As our data set was limited to September 1995, we used for comparison chl a concentration from synoptic sampling reported by Psarra et al. (1996). The same vertical pattern of chl a concentration was consistently and repeatedly reported in all vertical profiles. In the deeper water layers (below $100 \mathrm{~m}$ depth) chl a concentrations were generally $<0.01 \mathrm{\mu g} \mathrm{I}^{-1}$. The relative contribution of the different size classes to the total chl a pools is illustrated in Fig. 6. The largest fraction of chl a was associated with picophytoplankton, which accounted, on average, for $62 \%$ of the total chl a concentration, followed by nano- (on average $31 \%$ ) and microparticulate chl a (on average $7 \%$ ).

Phytoplankton DNA was estimated in the top $100 \mathrm{~m}$ of the water column using the conversion factor reported by Holm-Hansen (1969; $2 \mu \mathrm{g}$ DNA $\mu \mathrm{g}^{-1} \mathrm{chl}$ a). In order to provide phytoplankton DNA estimates for the 4 sampling periods the same factor was applied to data on chl a concentration summarised from Psarra et al. (1996). Phytoplankton DNA accounted on average for $17 \%$ of the total DNA, ranging from 10 to $28 \%$ in May and in February 1995, respectively.

\section{Particulate protein concentrations}

Spatial and temporal changes in particulate protein concentrations are reported in Fig. 7a. Protein concentrations did not change significantly among sampling periods and their distribution did not show a clear coast to open sea gradient. Protein concentrations decreased significantly ( $t$-test, $p<0.01$ ) with increasing water depth (on average $40.3 \pm 2.3 \mu \mathrm{g} \mathrm{l}^{-1}$ in surface waters and $26.8 \pm 3.5 \mathrm{\mu g} \mathrm{l}^{-1}$ in deeper water layers annually). The relative contribution of the different size classes to the total particulate protein pools is illustrated in Fig. 7 b. Picoparticulate proteins dominated at all sampling periods, accounting on average for $45 \%$ of the total protein pool. Picoparticulate protein contribution to the total pool decreased from August 1994 (on average $55 \%$ ) to September 1995 (on average 38\%), whereas microparticulate proteins showed an opposite pattern, increasing from 17 to $34 \%$. Nanoparticulate proteins did not show clear temporal changes.

\section{Bacterial parameters}

Bacterial density ranged from 0.94 to $9.52 \times 10^{8}$ cells $1^{-1}$ (on average $3.6 \times 10^{8}$ cells $1^{-1}$ ) and showed large temporal changes, with highest values in February and September 1995 (on average 4.70 and $3.91 \times 10^{8}$ cells $\mathrm{I}^{-1}$, respectively) and lowest values in August 1994 and May 1995 (2.76 and $2.58 \times 10^{8}$ cells $\mathrm{l}^{-1}$, respectively). In August 1994, free living bacteria (0.2 to $2 \mu \mathrm{m})$ accounted for the large majority (about $80 \%$ ) of the total bacterial density and picophytoplankton abundance was about 1 order of magnitude lower than total picoplankton abundance (data not shown). Vertical distribution of bacterial density showed clear decreasing patterns with depth in all sampling periods (Fig. 8), with the highest values in the top $50 \mathrm{~m}$. Bacterial DNA contribution to the total DNA pool (Fig. 9) was annually, on average, $40 \%$, but varied widely between sampling periods and with increasing distance from the coast. Highest bacterial DNA contributions were reported in February 1995 (on average $57 \%$ ), and lowest in August 1994 and May 1995 (on average 29 and $28 \%$, respectively). Bacterial DNA contribution to the total DNA pool decreased, although not significantly, from $43 \pm 11 \%$ in the surface waters to $30 \pm 12 \%$ in the deeper water layers.

\section{DISCUSSION}

\section{Spatial and temporal changes in particulate nucleic acids}

The Cretan Sea is among the most oligotrophic areas of the world, being characterised by the lowest primary production values of the entire Mediterranean (20 to $60 \mathrm{~g} \mathrm{C} \mathrm{m}^{-2} \mathrm{yr}^{-1}$; Dugdale \& Wilkerson 1988, Psarra et al. 1996) and very low inorganic nutrient concentrations $\left(0\right.$ to $0.76 \mu \mathrm{g}$-at. $\mathrm{PO}_{4} \mathrm{I}^{-1}$ and 0.2 to $0.9 \mu \mathrm{g}$-at. $\mathrm{NO}_{3}$ $\mathrm{I}^{-1} ; \mathrm{N}: \mathrm{P}>25$; Tselepides et al. 1996), chl a content (from 0.1 to $0.26 \mu \mathrm{g} \mathrm{I}^{-1}$ ) and phytoplankton abundance (from 
a
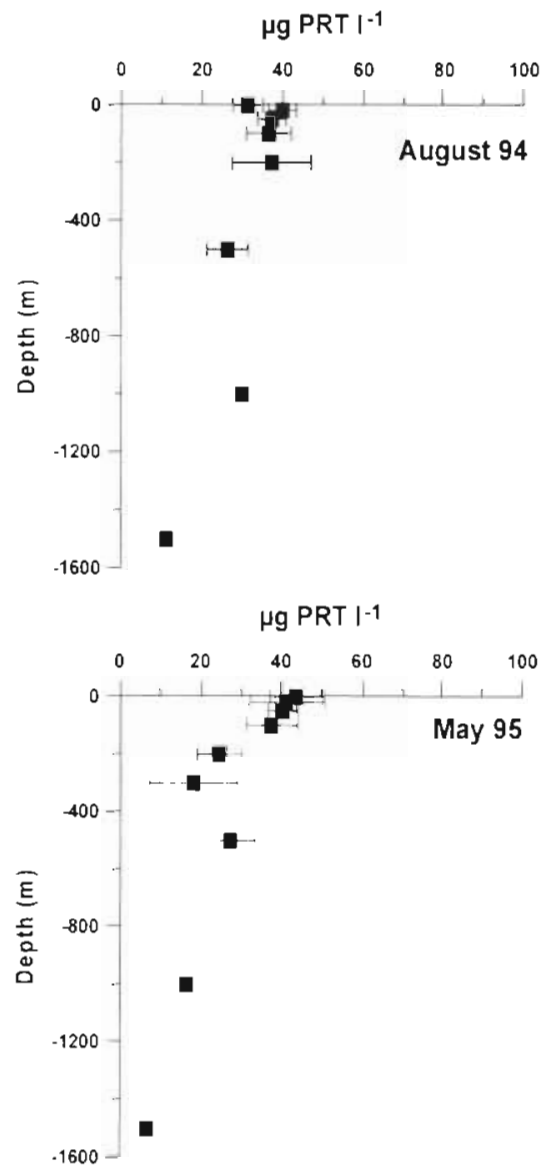

$\mu g$ PRT I ${ }^{-1}$
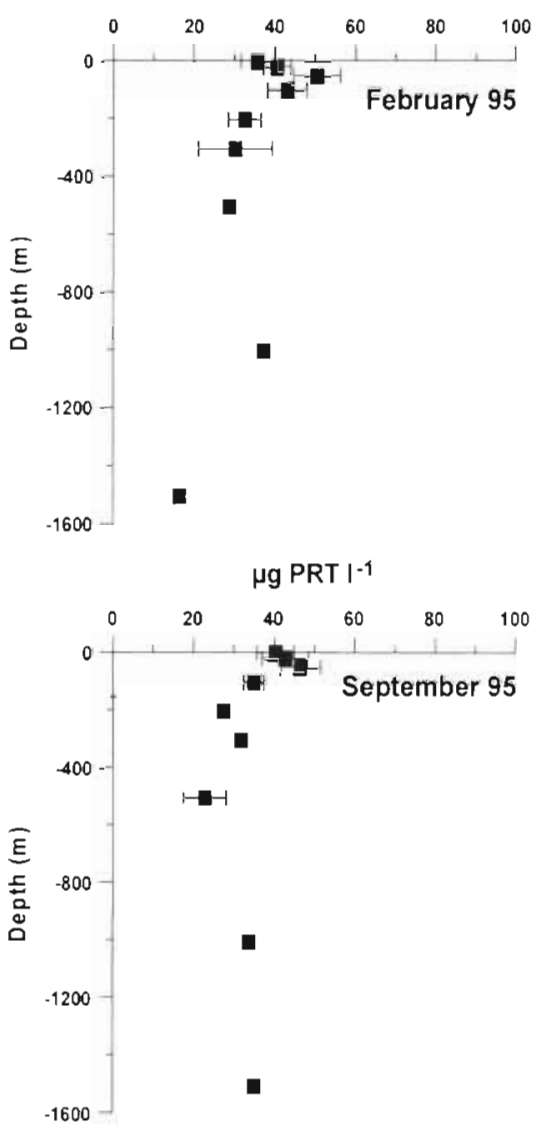

b

\section{Proteins}

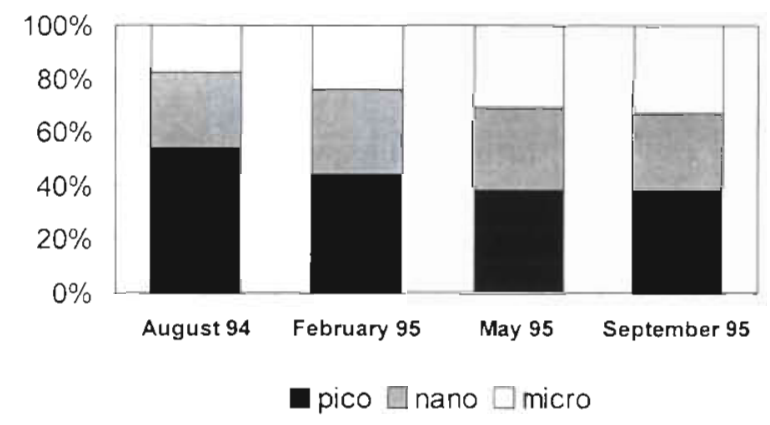

Fig. 7. Particulate protein concentrations (PRT) in the 4 sampling periods. Reported are: (a) vertical profiles (average values of all station at each sampling depth \pm standard errors) and (b) relative significance of the pico-, nano- and microparticulate fractions to the total particulate proteins
0.8 to $3.9 \times 10^{3}$ cells $^{-1}$, Psarra et al. 1996). These conditions are reflected by extremely low particulate organic matter concentrations (4 to 15 times lower than in other areas of the Mediterranean: Danovaro et al. in press a) and reduced POC fluxes (up to 2 orders of magnitude lower than in the Western Mediterranean; Chronis et al. 1996, Danovaro et al. in press b)

Nucleic acid concentrations reported in the present study confirm the oligotrophy of the Cretan Sea. In the top $100 \mathrm{~m}$ of the water column, total particulate DNA concentrations were comparable to those found in other highly oligotrophic systems, such as the Gulf of Mexico, but were up to 50 times lower than in estuarine environments (Table 1). On the other hand, particulate RNA concentrations were, together with those reported in offshore waters of the Western Mediterranean, the lowest reported so far in the marine environment (Table 1).

The reduced temporal variability in particulate DNA and protein concentrations (ratio of highest to lowest concentration: 1.3 and 1.1 , respectively) reflected the limited temporal changes reported for most water col- 


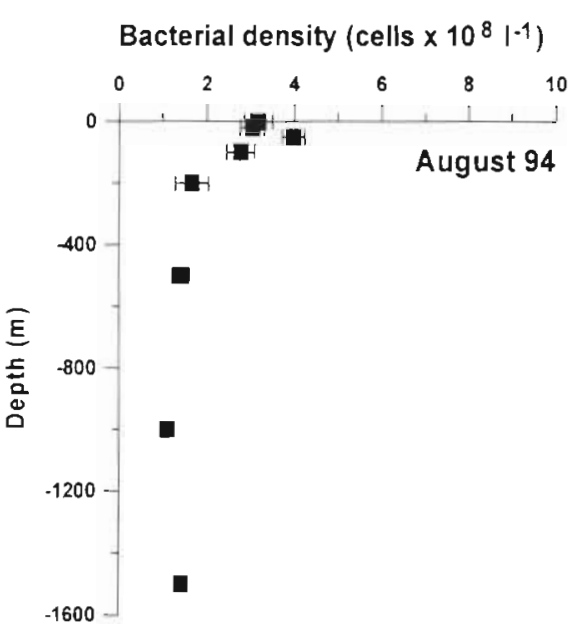

Bacterial density (cells $\times 10^{8} \mathrm{I}^{-1}$ )

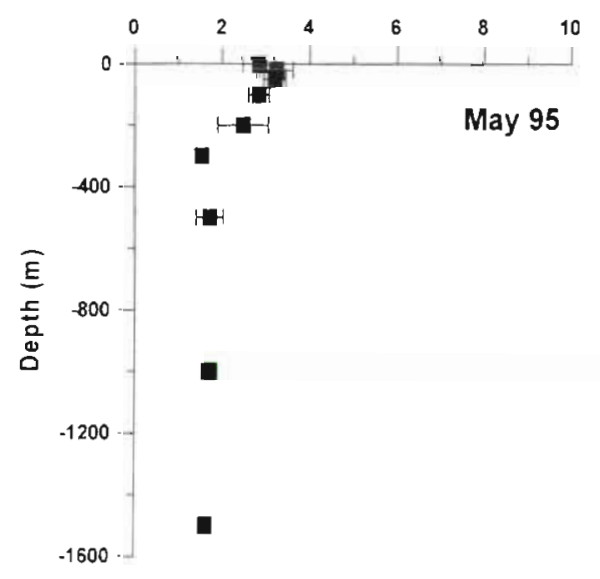

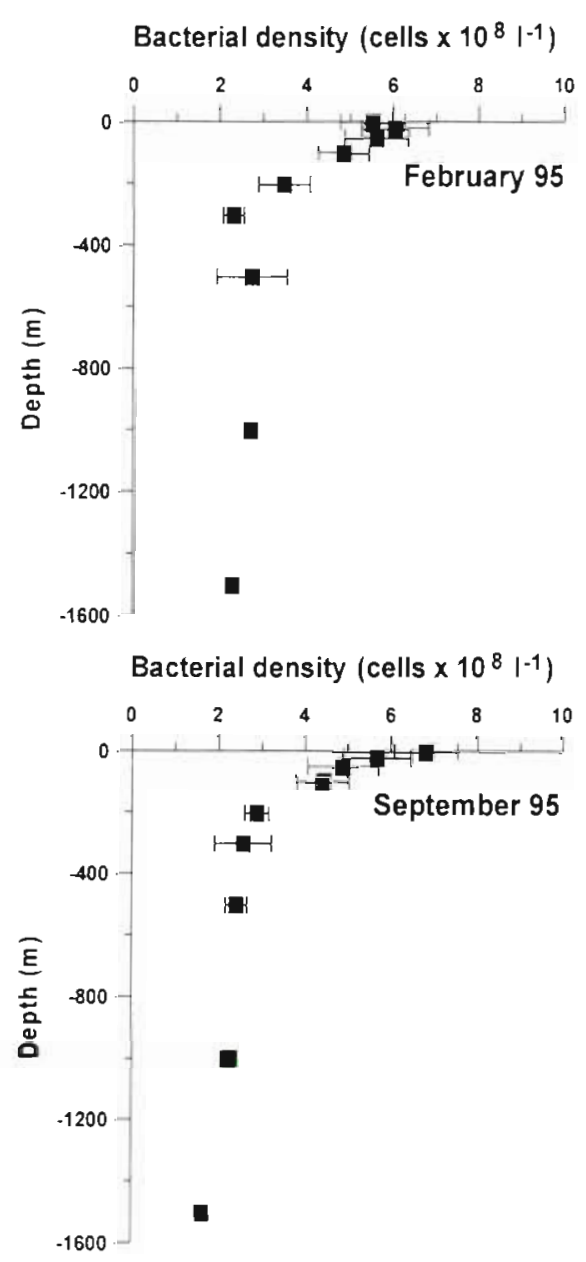

Fig. 8. Vertical distribution of bacterial density in the 4 sampling periods. Reported are average values of all sampled stations at each depth and relative standard errors
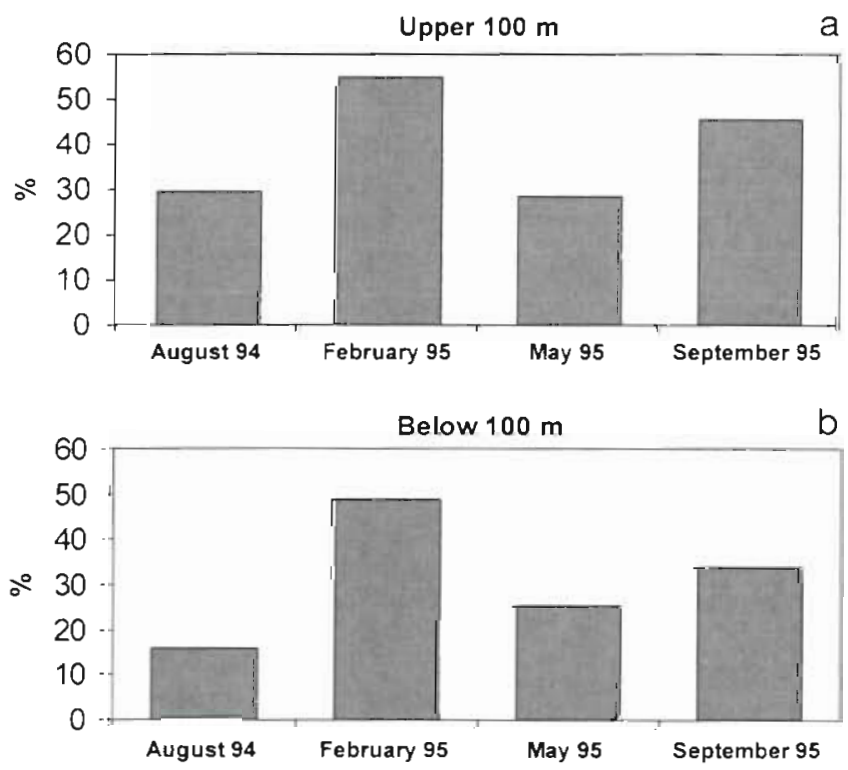

umn parameters such as POM concentrations (ratio of highest to lowest value: 1.3 ; Danovaro et al. in press a). By contrast, RNA concentrations displayed wider temporal changes (with a highest to lowest concentration ratio of 1.9). Similar temporal patterns and relatively higher variability were also reported for chl $a$ and primary production values (highest to lowest ratio: 2.1 and 1.6, respectively; Psarra et al. 1996). Moreover, in this study, higher particulate RNA concentrations were found in the top $50 \mathrm{~m}$ of the water column, where higher primary production values and phytoplankton densities were reported (Psarra et al. 1996). These data, although based on 4 sampling periods, suggest a coupling between RNA concentrations and autotrophic pracesses in this system. According to Berdalet \& Estrada (1993), who found similar relationships

Fig. 9. Bacterial contribution to particulate DNA pools (a) in the top $100 \mathrm{~m}$ of the water column and (b) below $100 \mathrm{~m}$ depth 
between primary productivity and RNA concentrations in the Western Mediterranean, higher RNA concentrations accompanying increasing photosynthetic activity might be explained by the increase of RNA concentrations per cell. At the same time, increased RNA concentrations could be due to an enhanced bacterial and/or microheterotrophic growth induced by bloom conditions (Painchaud \& Therriault 1989). In the Cretan Sea, bacterial secondary production (BSP) was coupled with primary production (PP) (both PP and BSP displayed highest values in February 1995: 252 and $131 \mathrm{mg} \mathrm{C} \mathrm{m} \mathrm{m}^{-2} \mathrm{~d}^{-1}$ at D2, respectively, for PP and BSP; Psarra et al. 1996). Moreover, BSP values (from synoptic samplings at Stns D2, D4, D7, summarised from Van Wambeke et al. 1996) and picoparticulate RNA concentrations displayed similar spatial patterns (Fig. 10). These results further suggest that RNA concentrations increase as result of enhanced metabolic activity, both autotrophic and heterotrophic.
Previous studies have generally reported a strong decrease in particulate DNA concentrations with increasing water depth: concentrations lower than $1 \mu \mathrm{g}$ DNA ${ }^{-1}$ have been consistently reported below $300 \mathrm{~m}$ depth (Paul \& Carlson 1984, Paul et al. 1985, DeFlaun et al. 1987, Boheme et al. 1993). By contrast, in the Cretan Sea the DNA vertical distribution did not show clear vertical patterns and appeared to be dependent upon physical water column structure. Higher DNA concentrations were generally associated with the high salinity (>38.95) TMW in summer, whereas a sharp decrease in DNA concentrations was observed in non-stratified conditions (i.e. February 1995). High levels of DNA in intermediate waters were also reported in the Sicily Straits between 300 and $500 \mathrm{~m}$ depth (Fabiano unpubl. data). The association between the highest DNA concentrations and TMW suggests the presence of an important input of allochthonous DNA into the Cretan Sea, probably deriving from lateral advection.

Table 1. Comparison of particulate DNA and RNA concentrations $\left(\mu \mathrm{g} \mathrm{l}^{-1}\right)$ in areas characterised by different trophic conditions. $\mathrm{NS}=$ nearshore $\mathrm{OS}=$ offshore $\mathrm{E}=$ estuarine $\mathrm{UA}=$ upwelling area; $\mathrm{nd}=$ not determined

\begin{tabular}{|c|c|c|c|c|}
\hline Area & Location & DNA & RNA & Source \\
\hline \multicolumn{5}{|l|}{ Antarctica } \\
\hline Bransfield Strait & OS & $1.2-5.4$ & nd & Bailiff \& Karl (1991) \\
\hline Ross Sea & OS & $1.0-72.8$ & $<1-170.5$ & Fabiano et al. (1993) \\
\hline Terra Nova Bay & NS & $13.7-94.6$ & $<2-156.1$ & Fabiano et al. (1996) \\
\hline Weddel Sea & NS & $1.0-5.3$ & nd & Karl \& Bailiff (1989) \\
\hline \multicolumn{5}{|l|}{ Mediterranean } \\
\hline W Mediterranean & OS & $0.2-2.1$ & $<0.1-6.7$ & Berdalet \& Dortch (1991) \\
\hline Ligurian Sea (NW Mediterranean) & NS & $9.1-23.0$ & nd & Danovaro \& Fabiano (1997) \\
\hline Ligurian Sea (NW Mediterranean) & NS & $8.8-19.9$ & $2.8-59.8$ & Danovaro et al. (1995) \\
\hline Catalan Sea (NW Mediterranean) & OS & $0.5-2.6$ & $1.2-12.2$ & Berdalet \& Estrada (1993) \\
\hline NW Mediterranean & OS & $1.2-3.3$ & $0.5-3.1$ & Fara et al. (1996) \\
\hline \multicolumn{5}{|l|}{ Atlantic } \\
\hline SE Gulf of Mexico & OS & $<1-6.2$ & nd & Boheme et al. (1993) \\
\hline SE Gulf of Mexico & OS & $0.6-8.32$ & nd & DeFlaun et al.(1987) \\
\hline SE Gulf of Mexico & NS & $10.6-28.7$ & nd & DeFlaun et al. (1987) \\
\hline Gulf Stream & OS & $2.0-7.0$ & nd & Holm-Hansen et al. (1968) \\
\hline Gulf Stream & OS & -8.6 & nd & Holm-Hansen et al. (1968) \\
\hline Gulf of Mexico & NS & $<0.1-60.0^{\mathrm{d}}$ & $<0.1-80.0^{\mathrm{d}}$ & Jeffrey et al. (1996) \\
\hline Atlantic Ocean & OS & $\sim 27$ & nd & Paul \& Myers (1982) \\
\hline Gulf of Mexico and Tampa Bay & NS & $10.6-19.6$ & nd & Paul et al. (1985) \\
\hline Gulf of Mexico and Tampa Bay & OS & $0.2-4.4$ & nd & Paul et al. (1985) \\
\hline \multicolumn{5}{|l|}{ Oceanic waters } \\
\hline Pacific Ocean & NS & $4.0-30.0$ & nd & Holm-Hansen (1969) \\
\hline California & UA & $1.0-6.8$ & $3.2-6.3$ & Mordy \& Carlson (1991) \\
\hline Pacific Ocean & OS & $0.8-2.4$ & nd & Winn \& Karl (1986) \\
\hline \multicolumn{5}{|l|}{ Estuarine } \\
\hline Chesapeake Bay & $\mathrm{E}$ & $\sim 47$ & nd & Paul \& Carlson (1984) \\
\hline Tampa Bay & $\mathrm{E}$ & $17.5-42.6$ & nd & Paul et al. (1985) \\
\hline \multicolumn{5}{|l|}{ This study } \\
\hline Cretan Sea (E-Med) Stns D1-D3 & NS & $0.8-5.2^{b}$ & $<0.1-3.8^{\mathrm{b}}$ & This study \\
\hline Cretan Sea (E-Med) Stns D4-D7 & OS & $0.8-5.9^{b}$ & $<0.1-3.4^{\mathrm{b}}$ & This study \\
\hline
\end{tabular}






Fig. 10. Bacterial secondary production (BSP) versus picoparticulate RNA concentrations (values are integrated to the top $100 \mathrm{~m}$ of the water column) at Stns D2, D4 and D7. Data for BSP were summarised from Van Wambeke et al. (1996)

\section{Nucleic acids in relation to particle size structure}

The most evident characteristic of this oligotrophic environment is the dominance of DNA associated with picoparticles (more than $60 \%$ of the total DNA pool). The values found here are in agreement with those reported by Paul \& Carlson (1984) and by Paul et al. (1985) for oceanic samples (picoparticulate DNA $<1 \mu \mathrm{m}$ accounting for more than $70 \%$ of the total DNA pool) and suggest that pico-particulate DNA dominance is a distinctive feature of oligotrophic systems. However, comparisons with previous studies must be viewed with caution. In fact, here picoparticulate DNA was defined according to Sieburth et al. (1978), as particles between 0.2 and $2 \mu \mathrm{m}$, while other authors identified the DNA associated with particles using different pore size filters (e.g. Paul \& Carlson 1984, Paul et al. 1985: 0.2 to $1.0 \mu \mathrm{m}$, Jeffrey et al. $1996: 0.2$ to $0.8 \mu \mathrm{m}$ ).

The relative significance of the 3 size classes reported for DNA (with a ratio 1:3:6 for micro-, nano- and picoparticulate DNA, respectively) was exactly the same as that of the chl a size fractions. By contrast, both particulate proteins and RNA displayed an average annual ratio of about $1: 1: 2$. Therefore, parameters that might be utilised as indicators of metabolic activity (such as RNA and proteins) display higher relative importance in the larger size classes (nano- and microparticles), whereas DNA (which is likely to be more detrital) is mostly associated with the smallest particles (i.e. with picoparticles).

Previous studies carried out in other oligotrophic areas of the Mediterranean have demonstrated, for all biochemical components, significant temporal changes in the particle size to which they were associated, and such changes were particularly evident during phytoplankton blooms (Fabiano et al. 1994). In contrast, the relative significance of the different size classes of
DNA in the present study did not display significant temporal changes in the top $100 \mathrm{~m}$ of the water column. The constancy of the DNA distribution among size classes in the photic layer might reflect the limited primary productivity of the system, related to the strong P deficiency (Berdalet et al. 1996, Tselepides et al. 1996). Interestingly, in May and September 1995 the nano- and microparticulate DNA fractions increased significantly below $100 \mathrm{~m}$ depth. There are 2 main explanations for this apparent anomaly: (1) DNA produced in the photic layer underwent aggregation during its sinking; (2) DNA concentrations observed under the photic layer originated from other areas being associated with specific water masses (e.g. TMW). This latter explanation is in agreement with evidence reported for the DNA vertical distribution described above.

\section{Bacterioplankton contribution to the total DNA pool}

In highly oligotrophic environments, where bacterioplankton largely dominates the system (Cho \& Azam 1990), the concentration and relative importance of picoparticulate DNA are likely to be related to bacterial density. Data from the present study confirm this expectation, as bacterioplankton was significantly correlated to the total DNA concentrations ( $\mathrm{n}=41, \mathrm{r}=$ $0.452, \mathrm{p}<0.01$ ) in February 1995 (when living DNA i.e. bacterial plus phytoplanktonic DNA - represented about $85 \%$ of the total DNA pool), whereas in other sampling periods no significant relationships were found.

In the northwestern Mediterranean, Berdalet \& Estrada (1993) found significant relationships between particulate DNA (using the same fluorescent dyes utilised in the present study) and chl a concentrations in February, during the phytoplankton bloom, but not in May. They concluded that the lack of correlations in certain periods of the year might be due to an increase in the relative importance of detrital DNA.

Whether picoparticulate DNA is related to picophytoplankton assemblages or to bacterioplankton density is largely dependent upon their relative significance. Bacterial densities in the Cretan Sea (range: 1.1 to 8.8 $\times 10^{8}$ cells $1^{-1}$ ) were rather high and similar to those reported in the surface waters of the Central-North Pacific (range 3 to $15 \times 10^{8}$ cells $\mathrm{l}^{-1}$; Cho \& Azam 1990) and in the Western Mediterranean (range 3 to $8 \times 10^{8}$ cells $1^{-1}$; Danovaro \& Fabiano 1997). Despite the large variability between sampling periods and due to the low nucleic acid concentrations, the bacterial DNA contribution to the total DNA pool in the Cretan Sea was high (on average $40 \%$ ). This value is higher than the bacterial contribution to the particulate DNA re- 
ported for the coastal waters of the Western Mediterranean (22\%; Danovaro \& Fabiano 1997), but matches exactly the contribution reported for the water surrounding a seagrass system of the Ligurian Sea (42\%; Danovaro et al. 1998). Similar bacterial contributions $(51 \%)$ were reported by Boheme et al. (1993) in the southeastern Gulf of Mexico, and even higher values were reported by other authors for surface oceanic samples (Paul \& Carlson 1984, Paul et al. 1985). Discrepancies in the estimates of the bacterial DNA contribution to the DNA pool might be due to the use of different conversion factors. For instance, the conversion factor utilised in this study $\left(2.5 \mathrm{fg}\right.$ DNA cell $\left.{ }^{-1}\right)$ was about half of that utilised by Boheme et al. (1993) (i.e. $5.66 \mathrm{fg}$ DNA cell ${ }^{-1}$ ) and about one-fourth of that estimated by Paul \& Carlson (1984) (on average $9.8 \mathrm{fg}$ DNA cell ${ }^{-1}$ ).

Paul et al. (1985) estimated the bacterial DNA content (i.e. $5.66 \mathrm{fg}$ DNA cell ${ }^{-1}$ ) from a linear regression between DNA content and bacterial counts (both in the fraction $<1 \mu \mathrm{m}$ ) and reported an intercept value of $2.66 \mu \mathrm{g}$ DNA $\mathrm{I}^{-1}$, which was assumed to represent the detrital DNA fraction. Applying the same calculation methods (based on picoparticulate DNA vs bacterial density in February 1995) we found a DNA content per bacterial cell ranging from 1.9 to $3.0 \mathrm{fg}$ DNA cell ${ }^{-1}$ (which is close to the one utilised) and an intercept of $0.51 \mu \mathrm{g} \mathrm{DNA} \mathrm{l}^{-1}$ (which indicates that in February 1995 , only $18 \%$ of the picoparticulate DNA was detrital; sensu Paul et al. 1985). Therefore, we might conclude that bacteria in the Cretan Sea played a role of primary importance as a living DNA component.

As phytoplankton DNA annually accounted on average for only $17 \%$ of the total DNA it can be concluded that in the Cretan Sea most of the living particulate DNA was associated with the heterotrophic bacterial component. Thus, as an annual average and for the entire water column, about $43 \%$ of the total DNA pool was associated with the microheterotrophic-detrital fraction.

Further studies, extended to the processes of transfer between particulate and dissolved DNA pools, will help clarify the importance of detrital DNA as a potential source of organic $\mathrm{N}$ and $\mathrm{P}$ for heterotrophic metabolism, especially in oligotrophic systems, where these nutrients might be limiting.

Acknowledgements. The authors thank the officers and the crew of the RV 'Philia', Dr A. Tselepides and T. Polychronaki (IMBC, Crete) for providing laboratory facilities and help during sampling, Dr P. Parodi (ISAM, Genova) for collaboration during sampling and Prof. N. Della Croce (ISAM, Genova) for supporting the entire research project. This research has been undertaken in the framework of the CINCS project. We acknowledge the support of the European Commission's MAST II under the contract MAS-2-CT94-0092

\section{LITERATURE CITED}

Bailiff DM, Karl DM (1991) Dissolved and particulate DNA dynamics during a spring bloom in the Antarctic Peninsula region, 1986-87. Deep-Sea Res 38:1077-1095

Berdalet E, Dortch Q (1991) New double-staining technique for RNA and DNA measurement in marine phytoplankton. Mar Ecol Prog Ser 73:295-305

Berdalet E, Estrada M (1993) Relationships between nucleic acid concentrations and primary production in the Catalan Sea (North-western Mediterranean). Mar Biol 117:163-170

Berdalet E, Marrase C, Estrada M, Arin L, MacLean ML (1996) Microbial community responses to nitrogen- and phosphorus-deficient nutrient inputs: microplankton dynamics and biochemical characterization. J Plankton Res 18:1627-1641

Boheme J, Frisher ME, Jiang SC, Kellog CA, Pichard S, Rose JB, Steinway C, Paul JH (1993) Viruses, bacterioplankton, and phytoplankton in the south-eastern Gulf of Mexico: distribution and contribution to oceanic DNA pools. Mar Ecol Prog Ser 97:1-10

Burney CM, Davis PG, Johnson KM, Sieburth JM (1979) Dependence of dissolved carbohydrate concentrations upon small scale nano-plankton and bacterioplankton distributions in the western Sargasso Sea. Mar Biol 65:289-296

Cho BC, Azam F (1990) Biogeochemical significance of bacterial biomass in the ocean's euphotic zone. Mar Ecol Prog Ser 63:287-298

Chronis G, Georgopoulos D, Lykousis V, Stavrakakis S, Poulos S, Karageorgis A, Iona A, Rousakis G, Georgiou P, Kioroglou $S$ (1996) Hydrology and suspended particulate matter (SPM) in the Cretan Sea. In: Tselepides A, Papadopoulou KN, Polychronaki T (eds) Pelagic-benthic coupling in the oligatrophic Cretan Sea. Final Report, CINCS, Heraklion, p $12-25$

Danovaro R (1998) Do bacteria compete with phytoplankton for inorganic nutrients? Possible ecological implications. Chem Ecol 14:83-96

Danovaro R, Fabiano M (1997) Seasonal changes in quality and quantity of food available for benthic suspension feeders in the Golfo Marconi (North-Western Mediterranean). Estuar Coast Shelf Sci 44:723-736

Danovaro R, Fabiano M. Albertelli G (1995) Possible use of RNA:DNA ratio for detecting oil induced disturbance: a field report. Chem Ecol 11:1-10

Danovaro R, Della Croce N, Fabiano M (1998) Biochemical composition of particulate organic matter and bacterial dynamics at the sediment-water interface in a Mediterranean seagrass system. Hydrobiol 363:241-251

Danovaro R, Dell'Anno A, Pusceddu A, Fabiano M (1999) Nucleic acid concentrations (DNA, RNA) in the continental and deep-sea sediments of the Eastern Mediterranean: relationships with seasonal varying organic inputs and bacterial dynamics. Deep-Sea Res I 46:1077-1094

Danovaro R, Dell'Anno A, Pusceddu A, Marrale D, Della Croce N, Fabiano M, Tselepides A (in press a) Biochemical composition of pico-, nano- and micro-particulate organic matter and bacterioplankton biomass in the oligotrophic Cretan Sea. Prog Oceanogr

Danovaro R, Della Croce N, Dell'Anno A, Fabiano M, Marrale $D$, Martorano D (in press b) Seasonal changes and biochemical composition of the labile organic matter flux in the Cretan Sea. Prog Oceanogr

DeFlaun MF, Paul JH, Jeffrey WH (1987) The distribution and molecular weight of dissolved DNA in subtropical estuarine and oceanic environments. Mar Ecol Prog Ser 38: $65-73$ 
Dell'Anno A, Duineveld GCA, Kok A, Fabiano M, Danovaro R (1998) Nucleic acid (DNA, RNA) quantification and RNA/DNA ratio determination in marine sediments: com.parison of spectrophotometric, fluorometric and high performance liquid chromatography methods and estimation of detrital DNA. Appl Environ Microbiol 64:3238-3245

Dugdale RC, Wilkerson FP (1988) Nutrient sources and primary production in the Eastern Mediterranean. Oceanol Acta 9:178-184

Fabiano M, Povero P, Danovaro R (1993) Distribution and composition of particulate organic matter in the Ross Sea (Antarctica). Polar Biol 13:525-533

Fabiano M, Misic C, Danovaro R (1994) Chemical and microscopic study of particulate proteins in Ligurian coastal waters. In: Proceedings of the Xth Congress of Italian Association of Limnology and Oceanography, Genova, p 355-366

Fabiano M, Povero P, Danovaro R (1996) Particulate organic matter composition in Terra Nova Bay (Ross Sea, Antarctica) during summer 1990. Antarc Sci 8:7-13

Fabiano M, Danovaro R, Povero P (1999) Vertical distribution and biochemical composition of pico- and micro-particulate organic matter in the Ross Sea (Antarctica). In: Spezie G. Manzella GMR (eds) Oceanography of the Ross Sea. Springer Verlag, Berlin, p 233-246

Fara A, Berdalet E, Arin L (1996) Determination of RNA and DNA concentrations in natural plankton samples using Thiazole Orange in combination with DNAse and RNAse digestions. J Phycol 32:1074-1083

Fuhrman JA, Sleeter TD, Carlson C, Proctor LM (1989) Dominance of bacterial biomass in the Sargasso Sea and its ecological implications. Mar Ecol Prog Ser 57:207-217

Hartree EF (1972) Determination of proteins: a modification of the Lowry method that gives a linear photometric response. Anal Biochem 48:422-427

Hobbie JE, Daley RJ, Jasper S (1977) Use of Nuclepore filters for counting bacteria by fluorescence microscopy. Appl Environ Microbiol 33:1225-1228

Holm-Hansen O (1969) Determination of microbial biomass in ocean profiles. Limnol Oceanogr 14:740-747

Holm-Hansen O, Sutcliffe WH, Sharp J (1968) Measurement of deoxyribonucleic acid in the ocean and its ecological significance. Limnol Oceanogr 13:507-514

Karl DM, Bailiff MD (1989) The measurement and distribution of dissolved nucleic acids in aquatic environments. Limnol Oceanogr 34:543-558

Jeffrey WH, Von Haven R, Hoch MP, Coffin RB (1996) Bacterioplankton RNA, DNA, protein content and relationships to rates of thymidine and leucine incorporation. Aquat Microb Ecol 10:87-95

Jørgensen NOG, Jacobsen CS (1996) Bacterial uptake and utilisation of dissolved DNA. Aquat Microb Ecol 11: $263-270$

Lee LG, Chen CH, Chiu LA (1986) Thiazole Orange: a new dye for reticulocyte analysis. Chytometry 7:508-517
Maruyama A, Oda M, Higashihara T (1993) Abundance of virus-sized non-Dnase digestible DNA (coated DNA) in eutrophic seawater. Appl Environ Microbiol 59:712-716

Mordy CW. Carlson DJ (1991) An evaluation of fluorescence techniques for measuring DNA and RNA in marine microorganisms. Mar Ecol Prog Ser 73:283-293

Painchaud J, Therriauld JC (1989) Relationships between bacteria, phytoplankton and particulate organic carbon in the Upper St. Lawrence Estuary. Mar Ecol Prog Ser 56:301-311

Paul JH, Carlson D (1984) Genetic material in the marine environment implication for bacterial DNA. Limnol Oceanogr 29:1091-1.097

Paul JH, Myers B (1982) Fluorometric determination of DNA in aquatic microorganisms by use of Hoechst 33258. Appl Environ Microbiol 43:1393-1399

Paul JH, Jeffrey WH, DeFlaun MF (1985) Particulate DNA in subtropical oceanic and estuarine planktonic environments. Mar Biol 90:95-101

Paul JH, Jeffrey WH, DeFlaun MF (1987) Dynamics of extracellular DNA in the marine environment. Appl Environ Microbiol 53:170-179

Psarra S, Tselepides A, Ignatiades L, Dafnomili E (1996) Primary production estimates in the Cretan Sea. In: Tselepides A, Papadopoulou KN, Polychronaki T (eds) PelagicBenthic coupling in the oligotrophic Cretan Sea. Final Report, CINCS, Heraklion, p 46-52

Sieburth JM, Smetacek V, Lenz J (1978) Pelagic ecosystem structure: heterotrophic compartments of the plankton and their relationship to plankton size fractions. Limnol Oceanogr 23:1256-1263

Simon M, Azam F (1989) Protein content and protein synthesis rates of planktonic marine bacteria. Mar Ecol Prog Ser 51:201-213

Tselepides A, Polychronaki T, Dafnomili E, Plaiti W, Zivanovic S (1996) Distribution of nutrients, oxygen, chloroplastic pigments, POC, PON and ATP in the Cretan Sea (NEMediterranean): seasonal and interannual variability. In: Tselepides A, Papadopoulou KN, Polychronaki T (eds) Pelagic-benthic coupling in the oligotrophic Cretan Sea. Final Report, CINCS, Heraklion, p 28-42

Van Wambeke F, Christaki U, Bianchi M (1996) Bacterial production estimates in the Cretan Sea. In: Tselepides A, Papadopoulou KN, Polychronaki T (eds) Pelagic-benthic coupling in the oligotrophic Cretan Sea. Final Report, CINCS, Heraklion, p 59-67

Winn CD, Karl DM (1986) Diel nucleic acid synthesis and particulate DNA concentrations: conflicts with division rate estimates by DNA accumulation. Limnol Oceanogr 31: $637-645$

Yentsch CS, Menzel DW (1963) A method for the determination of phytoplankton chlorophyll and phaeophytin by fluorescence. Deep-Sea Res 10:221-231

Zweifel U, Norrman B, Hagstrom A (1993) Consumption of dissolved organic carbon by marine bacteria and demand for inorganic nutrients. Mar Ecol Prog Ser 101:23-32

Submitted: January 22, 1999; Accepted: May 7, 1999

Proofs received from author(s): September 8, 1999 